\title{
Unmanned Surface Vehicle untuk Mencari Lokasi Tumpahan Minyak Menggunakan Ardupilot Mega
}

\author{
Dedy Permana, Muhammad Rivai, dan Astria Nur Irfansyah. \\ Departemen Teknik Elektro, Fakultas Teknologi Elektro, \\ Institut Teknologi Sepuluh Nopember (ITS) \\ E-mail:muhammad_rivai@ee.its.ac.id
}

\begin{abstract}
Abstrak-Minyak adalah sumber energi yang sering digunakan dalam dunia industri. Akhir-akhir ini penggunaan minyak meningkat yang dapat menyebabkan meningkatnya polusi minyak di perairan akibat dari tumpahan minyak mentah. Meningkatnya polusi minyak ini menjadi perhatian yang cukup serius di bidang lingkungan hidup. Akibat adanya polusi minyak ini menyebabkan sektor pariwisata kelautan menjadi tidak optimal dan dapat mencemari lingkungan laut. Pada penelitian ini telah dibuat suatu alat untuk mendeteksi tumpahan minyak di perairan berupa Unmanned Surface Vehicle (USV) yang dapat menyisir area dengan waypoint tertentu untuk mendeteksi lokasi dari tumpahan minyak. USV ini dilengkapi dengan sensor berupa sensor resistif yang digunakan untuk mendeteksi adanya tumpahan minyak di perairan. Agar USV dapat berjalan secara autonomous, maka digunakan Global Positioning System (GPS) untuk mengetahui keberadaan USV dan lokasi tumpahan minyak. GPS yang digunakan adalah tipe ublox neo $6 \mathrm{~m}$. IMU sensor MPU6000 digunakan untuk mengetahui arah dan kecepatan dari USV. Untuk mikrokontroler yang digunakan adalah Ardupilot Mega karena memiliki fitur yang meliputi sensor barometer, akselerometer, gyrometer dan magnetometer. USV dapat mendeteksi lokasi tumpahan minyak dengan metode waypoint yang diberikan pada ardupilot mega dengan ketebalan minyak minimal $3 \mathrm{~mm}$ dan maksimal $40 \mathrm{~mm}$. USV ini mampu mengirimkan data-data tersebut secara real time.
\end{abstract}

Kata Kunci-Ardupilot Mega, Navigasi Waypoint, Sensor Air, Tumpahan Minyak.

\section{PENDAHULUAN}

$\mathrm{S}^{\mathrm{n}}$ EBAGAI sumber energi yang sering digunakan, minyak sangat banyak permintaannya. Produk minyak memainkan peranan yang penting dalam bidang industri terutama transportasi. Dalam beberapa tahun terakhir, penggunaan minyak menjadi meningkat menyebabkan meningkatnya polusi minyak di perairan[1]. Polusi ini dapat disebabkan dari kecelakaan kapal tanker, kebocoran dari tangki bahan bakar kapal maupun pengeboran minyak lepas pantai[2].

Dikutip dari pemberitaan pada tanggal 6 Januari 2017 telah terjadi tabrakan kapal tanker yang menyebabkan 300 ton minyak tumpah. Tumpahan minyak dari kapal tanker tersebut dapat terbawa arus hingga memasuki wilayah perairan Indonesia. Dari kasus tersebut masih belum diketahui pasti lokasi dari tumpahan minyak yang memasuki wilayah perairan

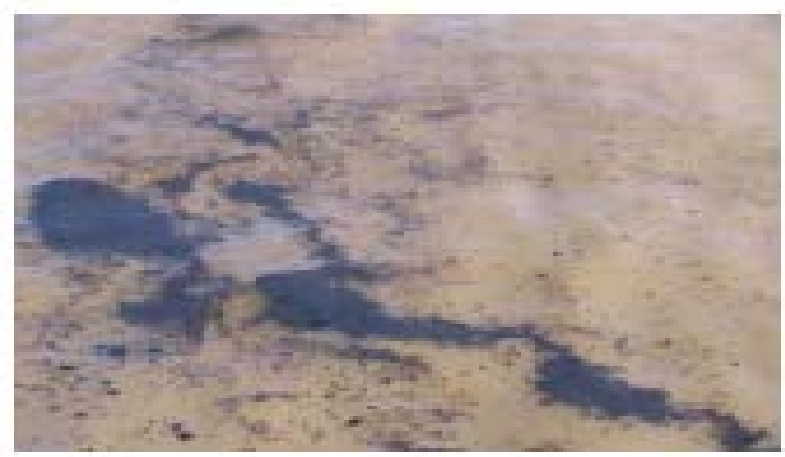

Gambar 1. Contoh tumpahan minyak di perairan laut.

Indonesia. Selama ini untuk mengetahui lokasi tumpahan minyak menggunakan Synthetic Aperture Radar (SAR atau Satelit Citra). Untuk mendapatkan data dari pengolahan citra ini memerlukan pemrosesan data yang cukup rumit. Adapula yang menggunakan Unmanned Aerial Vehicle (UAV atau pesawat tanpa awak) dengan menggunakan kamera sebagai pendeteksi cairan minyak yang berwarna hitam[1]. Sistem UAV ini memiliki kelemahan yaitu apabila mendeteksi benda hitam selain minyak yang berada di perairan akan dianggap seperti ada minyak serta tidak dapat memproses data secara real time. Hal ini dapat memberikan informasi yang kurang akurat.

\section{TEORI PENUNJANG}

\section{A. Karakteristik Minyak}

Minyak adalah istilah umum untuk segala cairan organik yang tidak bercampur dengan air namun larut pada pelarut organik[3]. Minyak mempunyai molekul yang bersifat non polar. Molekul non polar yang diberi medan listrik luar akan mengakibatkan sebagian muatan terinduksi dan menghasilkan momen dipol yang besar dan arahnya sebanding dengan medan listrik luar[4].

Sifat listrik dari setiap bahan memiliki nilai yang khas dan besarnya ditentukan oleh sifat dari bahan tersebut, seperti komposisi bahan, ikatan molekul, kandungan air, dan kondisi lainnya. Pengukuran sifat listrik dapat digunakan untuk mengetahui suatu keadaan dan kondisi dari suatu bahan, menentukan kualitas bahan dan pengukuran kadar air secara non destruktif[4].

\section{B. Sensor Konduktivitas}

Sensor konduktivitas dapat digunakan sebagai alat ukur daya hantar listrik dari suatu fluida. Sebagai contoh alat ini berperan penting dalam kelancaran proses, oleh karenanya sensor ini dapat mengukur, mengontrol, mendeteksi dan menganalisa suatu input dengan baik dan benar[5]. 
Konduktivitas dapat diukur dengan memberikan arus pada dua elektroda yang ditenggelamkan pada larutan dan mengukur resultan tegangannya. Pada proses ini, kation akan menuju ke arah elektroda negatif, anion akan menuju kearah elektroda positif dan larutan menjadi konduktor listrik seperti terlihat pada Gambar 2.

\section{Unmanned Surface Vehicle}

Unmanned Surface Vehicle atau USV adalah kapal tanpa awak yang mampu menyusuri perairan secara otomatis. USV mampu bergerak diatas permukaan air secara otomatis dari satu titik ke titik yang lain dengan bantuan sistem navigasi GPS[6].

\section{Kapal dengan Lambung multihull}

Lambung kapal (hull) merupakan bagian dari kapal. Lambung kapal memberikan daya apung agar kapal tidak tenggelam. Rancang bangun kapal merupakan hal yang penting dalam membuat kapal karena perancangan ini berkaitan dengan pelabuhan yang akan disinggahi dan kedalaman jalur pelayaran yang akan dilalui oleh kapal tersebut[7].

Kapal multi lambung disebut dengan nama catamaran untuk kapal dengan lambung ganda dan trimaran untuk kapal dengan tiga lambung. Kapal ini mempunyai lambung yang besar, mempunyai kecepatan yang beragam, berkecepatan tinggi hingga rendah. Jenis kapal ini sering digunakan untuk penelitian di perairan laut karena lambung gandanya membuat kapal ini lebih stabil ketika terkena ombak.

\section{E. Mekanik Kemudi Kapal}

Mekanik kemudi kapal terdiri dari dua komponen utama, yaitu rudder kapal sebagai pengendali belok pada kapal dan propeller yang dihubungkan dengan motor untuk mengatur kecepatan dari kapal.

\section{F. Aktuator Kendali Kapal}

Aktuator yang digunakan sebagai pengendali dari mekanik kemudi prototype USV pada penelitian ini terdiri atas dua komponen utama yaitu motor brushless yang digunakan untuk menggerakkan propeller dan motor servo yang digunakan untuk menggerakkan rudder kapal.

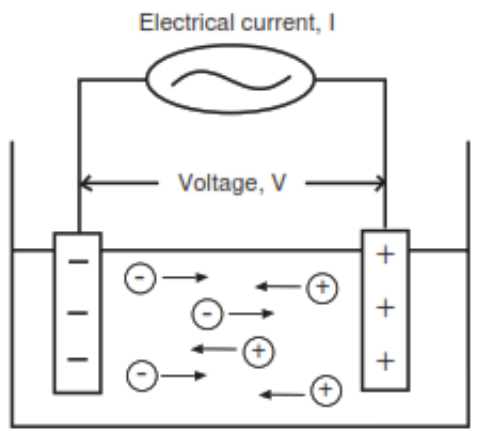

Gambar 2. Pergerakan ion terhadap elektroda.

\section{G. Modul Ardupilot Mega}

Ardupilot mega (APM) adalah kontroler yang berbasis dari arduino mega dan flight controller yang berbasis open source. Modul ini dapat mengatur pesawat bersayap, helikopter, multirotor, maupun wahana yang berada di darat seperti kapal ataupun mobil. Ardupilot ini memliki sistem kendali otomatis penuh untuk stabilisasi waypoint based navigation, dan komunikasi dua arah menggunakan telemetri[8][8].

Salah satu aplikasi yang telah disesuaikan dengan modul APM ini adalah mission planner yang digunakan sebagai aplikasi pengaturan dan penentu parameter waypoint untuk rute navigasi[9], [10].

\section{H. Modul Arduino Uno}

Arduino uno adalah mikrokontroler yang berbasis atmega 328p, memilik 14 digital input/output pin dimana 6 pinnya dapat digunakan sebagai keluaran PWM, 6 masukan analog, kristal 16MHz, koneksi USB, port power, dan tombol reset. "Uno" memiliki arti satu dalam bahasa Italia dan dipilih sebagai simbol dari peluncuran Arduino Software (IDE)[11].

\section{PERANCANGAN DAN PEMBUATAN}

\section{A. Perancangan Mekanik}

Perancangan mekanik pada penelitian ini terdiri dari perancangan lambung kapal, serta sistem kemudi yang mengatur arah gerak pada kapal. Perancangan kerangka lambung kapal dapat dilihat pada Gambar 3.

\section{B. Perancangan Sistem Elektrik Kapal}

Perancangan sistem elektrik pada kapal tanpa awak (USV) ditunjukkan pada Gambar 4. Hardware dirancang secara sederhana dan compact. Catu daya dihasilkan oleh baterai 11.1 Volt berjenis Li-Po berukuran 5000mAh.

Sistem elektronik pada kapal ini berbasis AVR embedded system yang terdiri dari ardupilot mega sebagai pengatur jalannya kapal dan arduino uno sebagai pemrosesan data sensor.

\section{Perancangan Sistem Navigasi}

Perancangan sistem navigasi pada kapal terdiri dari sistem navigasi otomatis waypoint dan perancangan sistem navigasi manual. Sistem navigasi waypoint merupakan salah satu sistem navigasi otomatis yang mengacu pada titik-titik waypoint berupa koordinat longitude dan latitude yang telah ditentukan. Pada penelitian ini sistem navigasi waypoint menggunakan ardupilot mega (APM). Modul APM telah mendukung sistem yang dapat diterapkan pada kapal yang telah diintegrasikan dengan GPS Ublox Neo 6m dan kompas digital. Sedangkan sistem navigasi manual pada kapal digunakan untuk dapat menggerakkan kapal secara manual menggunakan remote kontrol (RC) apabila terjadi error atau menggerakkan kapal menuju tempat tertentu yang tidak dapat dijangkau pada sistem navigasi otomatis.

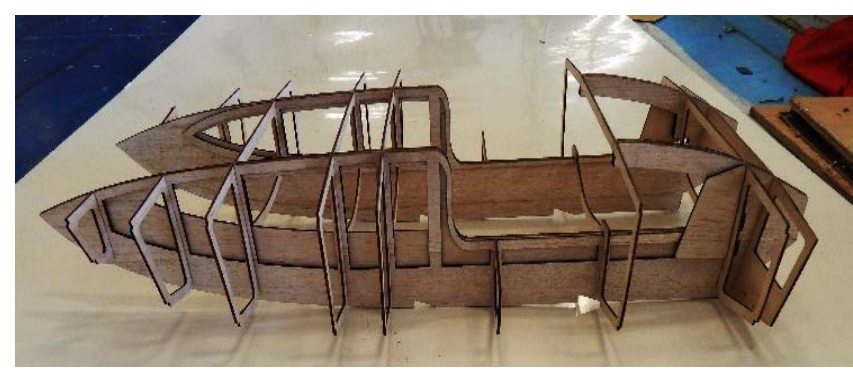

Gambar 3. Kerangka lambung kapal.

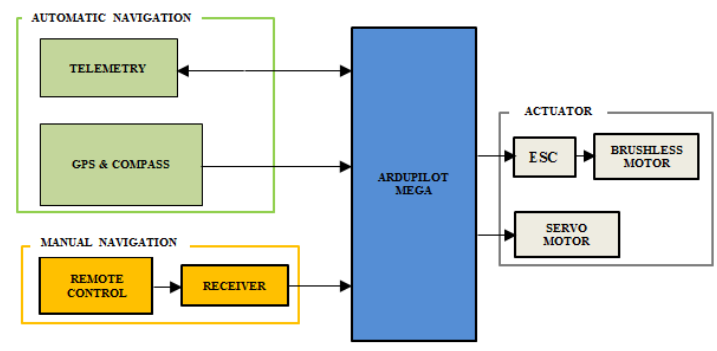

(a) 


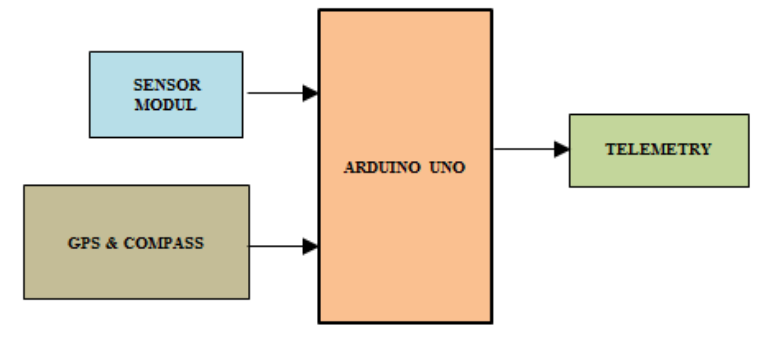

(b)

Gambar 4. (a) Blok diagram sistem elektrik pada USV, (b) Blok diagram sistem pendeteksi minyak.

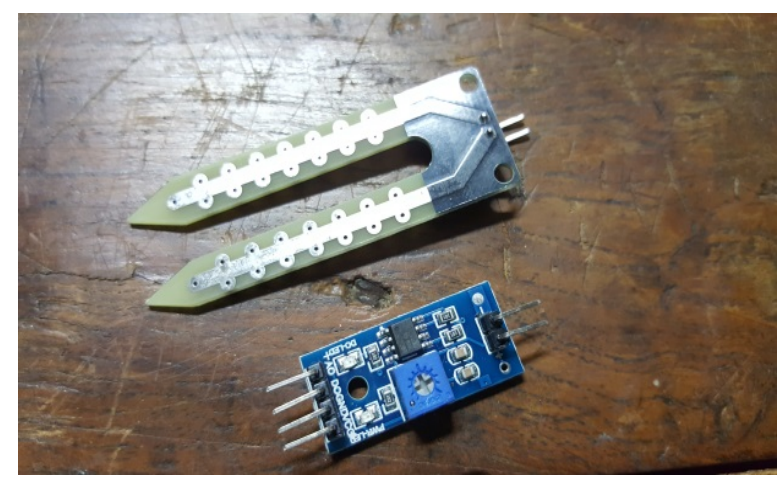

Gambar 5. Modul sensor cairan YL-69.

\section{Perancangan Sensor}

Perancangan sensor pendeteksi minyak di perairan menggunakan dua buah probe yang dialiri oleh arus listrik. Pada penelitian ini digunakan sebuah modul sensor cairan YL-69 seperti pada Gambar 5. Pada modul tersebut terdapat dua buah probe yang kemudian dialiri arus oleh rangkaian pembagi tegangan.

\section{E. Perancangan Sistem Komunikasi Kapal dengan Ground Control Station}

Perancangan sistem komunikasi kapal menggunakan sebuah modul radio telemetry yang telah terintegrasi dengan sistem autonomous pada kapal. Perancangan sistem komunikasi ini dilakukan dengan mengirimkan data secara terus menerus untuk sistem autonomous dan mengirimkan data lokasi apabila sensor mendeteksi adanya minyak pada perairan yang dilalui oleh kapal dengan memanfaatkan modul radio telemetry.

\section{PENGUJIAN DAN ANALISA}

\section{A. Pengujian Lambung Kapal.}

Pengujian lambung kapal bertujuan untuk mengetahui seberapa besar daya tampung payload pada kapal. Prosedur untuk pengujian lambung kapal antara lain:

a. Proses pembebanan payload kapal dilakukan secara bertahap dengan melakukan penambahan beban sebesar $1 \mathrm{~kg}$.

b. Proses pembebanan kapal didasarkan pada titik bagian lambung kapal yang masuk kedalam air dengan maksimal ketinggian $6 \mathrm{~cm}$ seperti yang ditunjukkan pada Gambar 6.

Hasil dari pengujian pembebanan lambung kapal tertera pada Tabel 1. Berdasarkan data pengujian dapat diketahui karakteristik lambung kapal yang menampung beban maksimal pada payload sebesar $4 \mathrm{~kg}$ untuk mencapai kestabilan saat berada di air dengan prosentase titik apung sebesar $87 \%$.

\section{B. Pengujian Sistem Aktuator}

Tujuan dari pengujian ini adalah untuk mengetahui karakteristik dari motor servo dengan pengaturan input duty cycle PWM dari mikrokontroler dan mendapatkan nilai PWM yang dibutuhkan oleh motor servo untuk setiap perubahan sudut 0 sampai 180 derajat. Hasil dari pengujian ini dapat dilihat pada Tabel 2.

Dari hasil pengujian dapat diketahui perubahan sudut servo berkerja pada duty cycle $5-10 \%$ atau pada periode high (Th) 1-2 ms dengan frekuensi $50 \mathrm{~Hz}$. Perubahan duty cycle diatur oleh mikrokontroler sebagai sistem pengaturan nilai PWM yang masuk pada input motor servo untuk menentukan sudut motor servo.

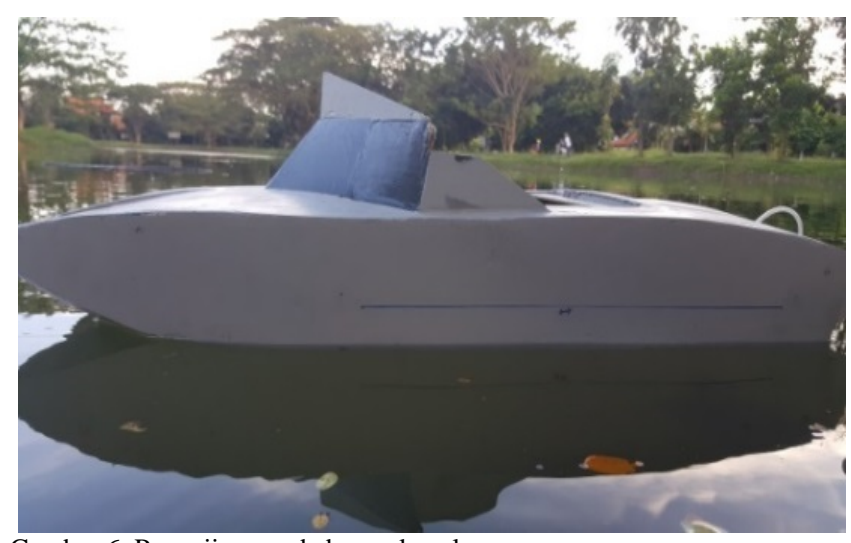

Gambar 6. Pengujian pembebanan kapal.

Tabel 1.

Data pengujian pembebanan pada kapal.

\begin{tabular}{cccc}
\hline \hline No & $\begin{array}{c}\text { Berat payload } \\
\text { (gram) }\end{array}$ & $\begin{array}{c}\text { Tinggi Titik } \\
\text { Apung (cm) }\end{array}$ & $\begin{array}{c}\text { Titik Apung } \\
\text { Kapal (\%) }\end{array}$ \\
\hline 1 & 0 & 1,0 & $17 \%$ \\
2 & 1000 & 1,9 & $32 \%$ \\
3 & 2000 & 3,1 & $52 \%$ \\
4 & 3000 & 4,1 & $68 \%$ \\
5 & 4000 & 5,2 & $87 \%$ \\
6 & 5000 & 6,3 & Overload \\
\hline \hline
\end{tabular}

Tabel 2.

Data pengujian perubahan sudut motor servo.

\begin{tabular}{|c|c|c|c|c|c|}
\hline \multirow{2}{*}{$\begin{array}{c}\text { Duty Cycle } \\
\text { (\%) }\end{array}$} & \multicolumn{2}{|c|}{ Periode Output } & \multicolumn{2}{|c|}{$\begin{array}{c}\text { Pergerakan Sudut } \\
\text { Servo (Derajat) }\end{array}$} & \multirow{2}{*}{ Error \% } \\
\hline & Th(ms) & $\mathbf{T}(\mathrm{ms})$ & $\begin{array}{c}\text { Hasil } \\
\text { Pengujian }\end{array}$ & Teori & \\
\hline 5,0 & 0,25 & 20 & 0 & 0 & $0,00 \%$ \\
\hline 5,6 & 0,28 & 20 & 20 & 20,2 & $1,00 \%$ \\
\hline 6,1 & 0,31 & 20 & 40 & 39,8 & $0,50 \%$ \\
\hline 6,7 & 0,33 & 20 & 60 & 60,2 & $0,33 \%$ \\
\hline 7,2 & 0,36 & 20 & 80 & 80.9 & $1,13 \%$ \\
\hline 7,5 & 1,50 & 20 & 90 & 90 & $0,00 \%$ \\
\hline 7,8 & 1,56 & 20 & 100 & 100,2 & $0,20 \%$ \\
\hline 8,1 & 1,61 & 20 & 110 & 109,6 & $0,36 \%$ \\
\hline 8,3 & 1,67 & 20 & 120 & 120,2 & $0,17 \%$ \\
\hline 8,9 & 1,78 & 20 & 140 & 139,6 & $0,29 \%$ \\
\hline 9,4 & 1,89 & 20 & 160 & 160,4 & $0,25 \%$ \\
\hline 10,0 & 2,00 & 20 & 180 & 180 & $0,00 \%$ \\
\hline
\end{tabular}




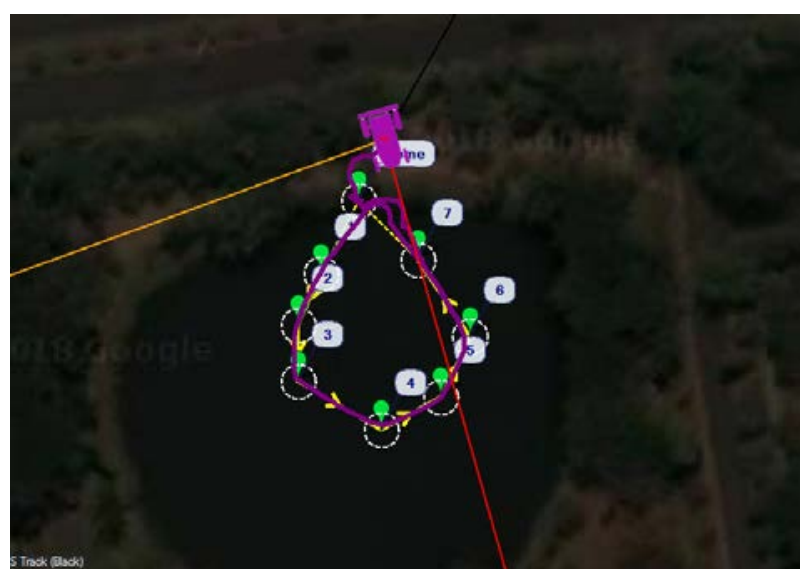

(a)

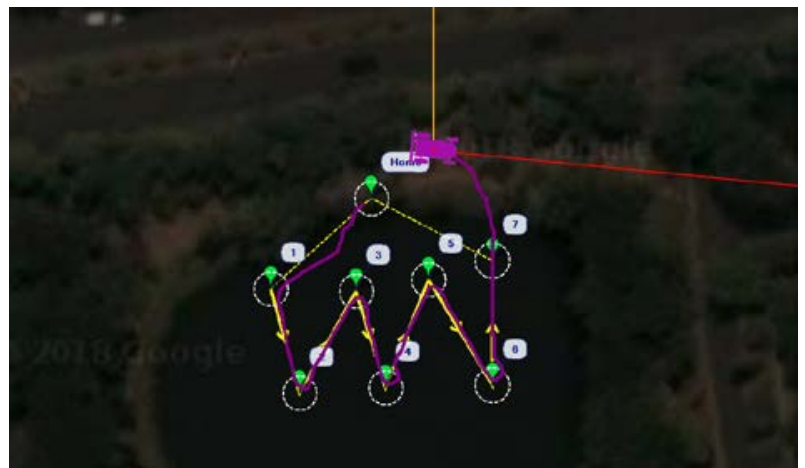

(b)

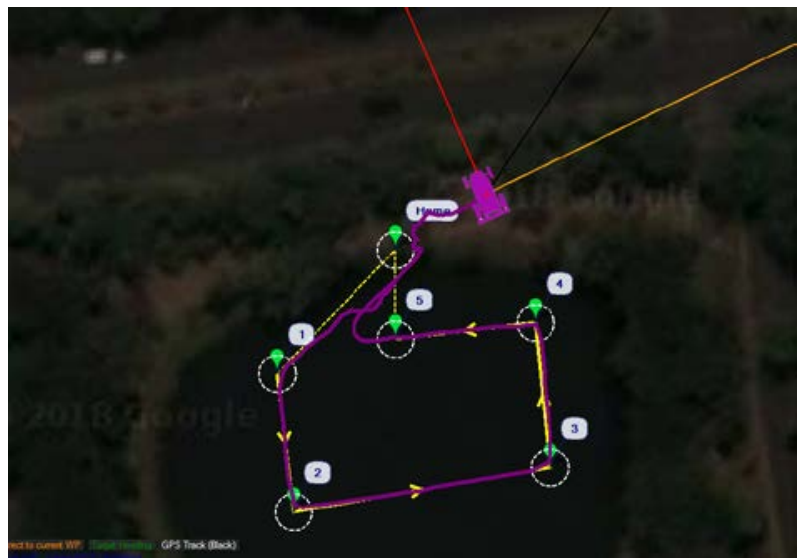

(c)

Gambar 7. Hasil pengujian sistem navigasi waypoint, (a) lintasan melingkar, (b) lintasan zig-zag, (c) lintasan kotak.

\section{Pengujian Sistem Navigasi}

Pengujian navigasi ini bertujuan untuk mengetahui tingkat akurasi GPS dalam pencapaian target waypoint yang telah ditentukan pada sistem navigasi. Sistem navigasi menggunakan modul ardupilot yang telah terintegrasi dengan GPS u-blox NEO-6M dan digital kompas HMC5883L. Pengujian sistem navigasi waypoint ardupilot mega ditunjukkan pada Gambar 7. Terlihat bahwa pergerakan kapal telah berhasil mengikuti garis lintasan yang telah diberikan dari mision planner.

\section{Pengujian Sensitivitas Sensor Pendeteksi Minyak}

Pengujian ini bertujuan untuk mengetahui tingkat sensitivitas dari sensor cairan dalam mendeteksi adanya minyak dan air. Sistem pengambilan data dilakukan dengan memberi air pada wadah tertentu dengan diameter $8 \mathrm{~cm}$ dan tinggi $12 \mathrm{~cm}$ yang diisi dengan air setinggi $4 \mathrm{~cm}$. Hasil pembacaan pada ADC pada saat air tersebut yaitu $379 \sim 381$. Kemudian pada wadah akan ditambahkan minyak hingga nilai sensor berubah secara signifikan, dan didapatkan nilai ADC yang berubah secara signifikan yaitu naik 10 angka menjadi 390 (389 391) saat ketebalan minyak sebebsar $3 \mathrm{~mm}$

\section{E. Pengujian Sensor Pendeteksi Minyak}

Pada pengujian sensor pendeteksi minyak ini bertujuan untuk mengetahui apakah metode konduktivitas dapat mendeteksi adanya minyak dan mengetahui tingkat keakurasian pembacaan dari sensor. Hasil pengujian dapat dilihat pada Tabel 3. Kemudian didapatkan grafik karakteristik sensor seperti pada Gambar 8.

\section{F. Pengujian Komunikasi Radio Telemetry}

Pengujian dari sistem komunikasi radio telemetry bertujuan untuk mengetahui efisiensi dan jarak maksimal dari sistem pengiriman data dari kapal menuju ke ground control station yang berada di daratan. Hasil pengujian dapat dilihat pada Tabel 4.

\section{G. Pengujian Keseluruhan Sistem}

Pengujian keseluruhan sistem ini bertujuan untuk mengetahui tingkat ketercapaian sistem dalam melakukan navigasi berdasarkan titik koordinat GPS pada lokasi pengujian serta menguji keberhasilan pendeteksian sensor secara real time. Pada pengujian sensor pendeteksian minyak dilakukan dalam skala laboratorium. Hasil pengujian menunjukkan bahwa sensor berhasil mendeteksi apabila terdapat minyak pada air dan akan mengirimkan lokasi saat sensor mendeteksi adanya tumpahan minyak ke ground control station. Pengujian sensor pendeteksi minyak dapat dilihat pada Gambar 9 dan hasil pengujian dapat dilihat pada Tabel 5.

Untuk pengujian keseluruhan sistem, sensor pendeteksi minyak dipasang pada lambung kapal seperti pada Gambar 10 yang kemudian dipantau pembacaan ADC nya dan kemudian diberi minyak dan diamati apakah sistem dapat mengirimkan lokasi dari tempat pengujian menuju ground control station.

Tabel 3.

Hasil pengujian sensor pendeteksi minyak.

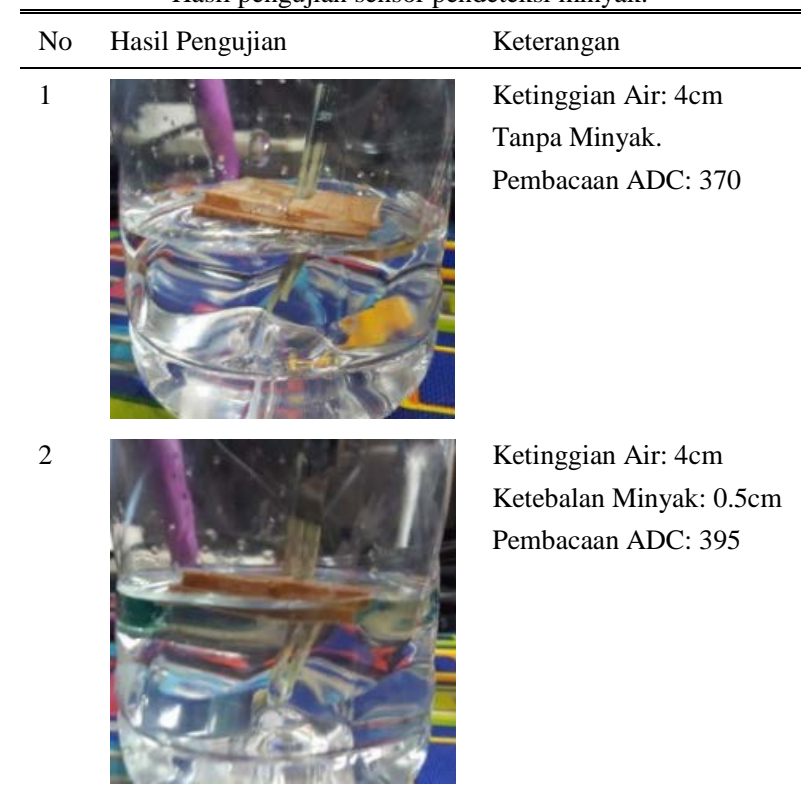


3

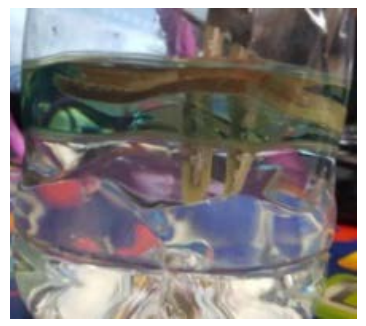

4

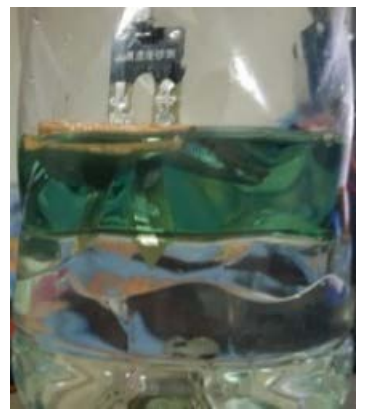

5

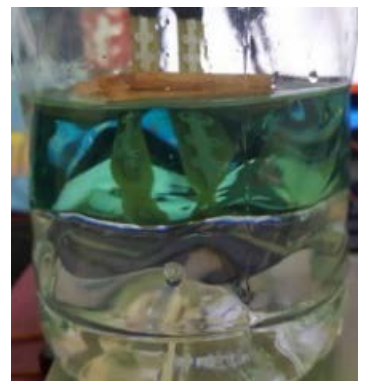

6

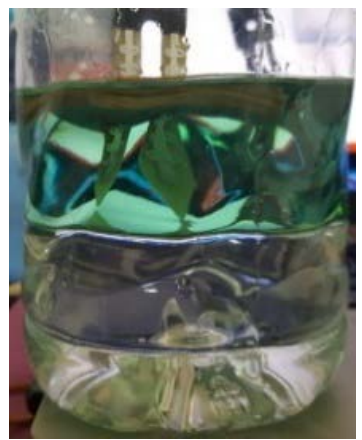

Ketinggian Air: 4cm Ketebalan Minyak: 3cm Pembacaan ADC: 682

Ketinggian Air: $4 \mathrm{~cm}$ Ketebalan Minyak: $4 \mathrm{~cm}$ Pembacaan ADC: 799

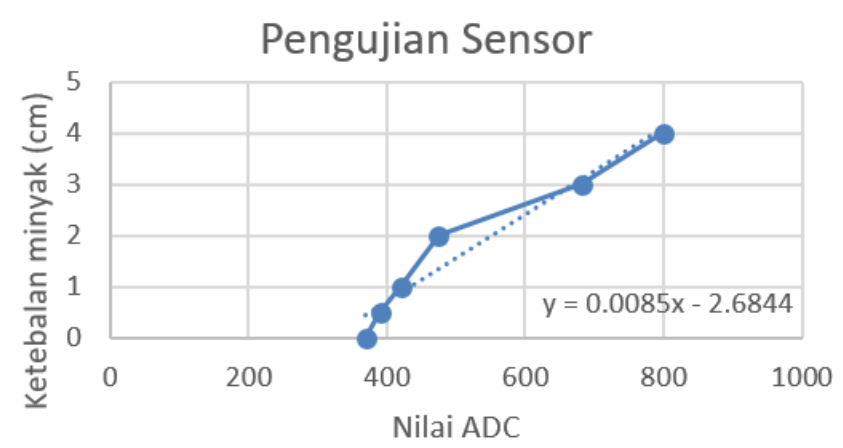

Gambar 8. Grafik perubahan nilai ADC terhadap ketebalan minyak.

Tabel 4.

Hasil pengujian komunikasi radio telemetry.

\begin{tabular}{ccccc}
\hline \hline No & Frekuensi & Jarak Pengujian & Hasil Pengujian & Keterangan \\
\hline 1 & $915 \mathrm{MHz}$ & 100 meter & Berhasil & \\
2 & $915 \mathrm{MHz}$ & 200 meter & Berhasil & \\
3 & $915 \mathrm{MHz}$ & 300 meter & Berhasil & Pengujian di \\
4 & $915 \mathrm{MHz}$ & 400 meter & Berhasil & lokasi / area \\
5 & $915 \mathrm{MHz}$ & 500 meter & Berhasil & terbuka \\
6 & $915 \mathrm{MHz}$ & 600 meter & Berhasil & (outdoor) \\
7 & $915 \mathrm{MHz}$ & 700 meter & Gagal & \\
\hline \hline
\end{tabular}

Dari hasil pengujian, kapal dapat berjalan secara autonomous dan mengirimkan data sensor secara realtime ke ground control station menggunakan radio telemetry seperti terlihat pada Gambar 11.

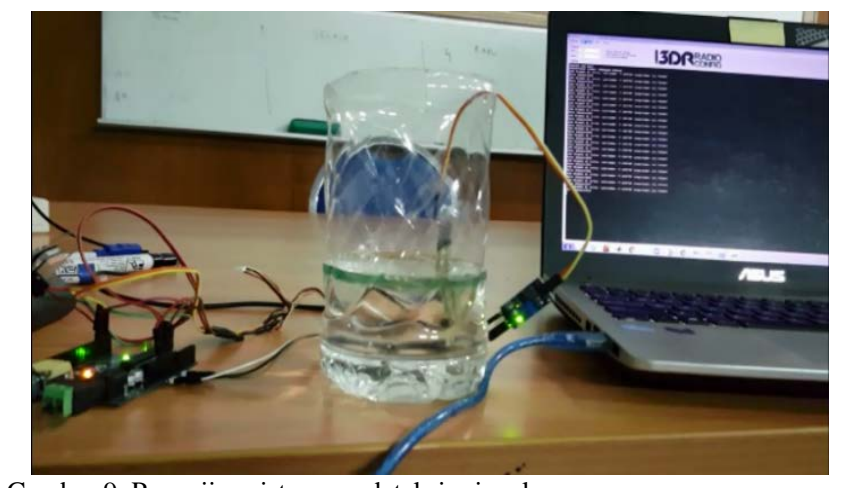

Gambar 9. Pengujian sistem pendeteksi minyak.

Tabel 5.

Hasil pengujian pendeteksian minyak di air.

\begin{tabular}{lcl}
\hline \hline Percobaan ke- & Air & Air dengan Minyak \\
\hline 1 & Tidak Terdeteksi & Terdeteksi \\
2 & Tidak Terdeteksi & Terdeteksi \\
3 & Tidak Terdeteksi & Terdeteksi \\
4 & Tidak Terdeteksi & Terdeteksi \\
\hline \hline
\end{tabular}

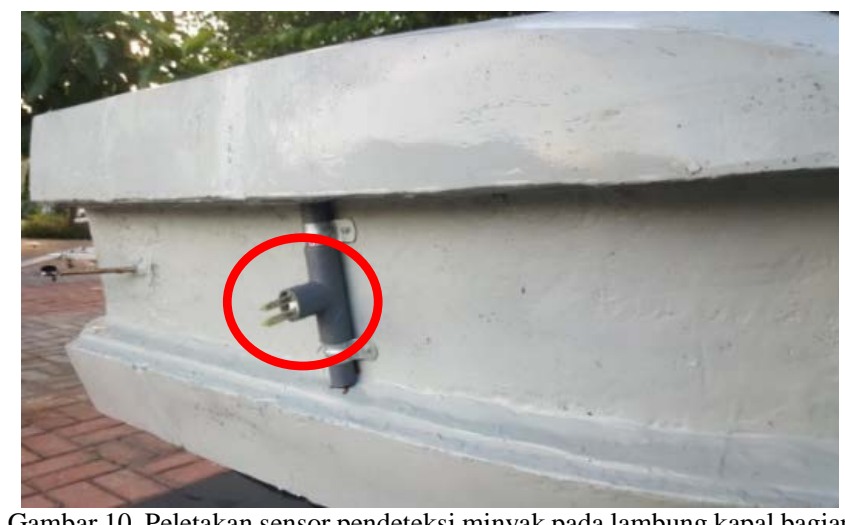

Gambar 10. Peletakan sensor pendeteksi minyak pada lambung kapal bagian bawah.

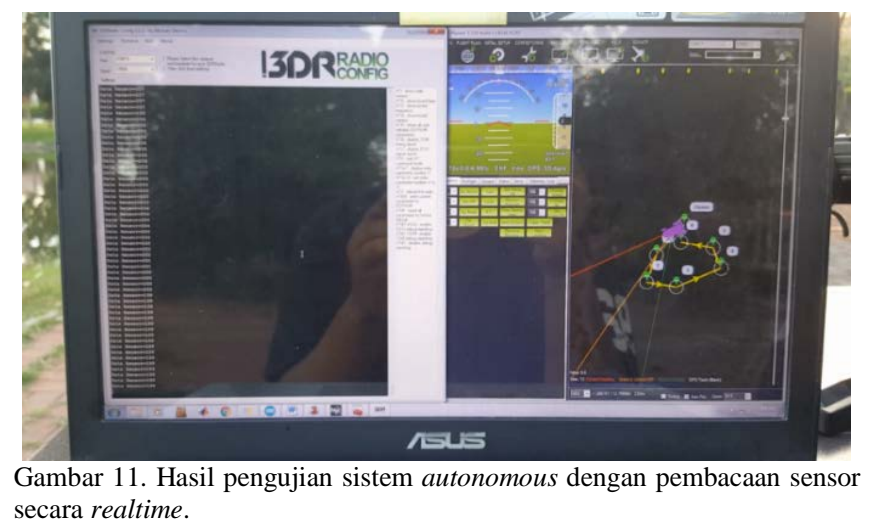

\section{KESIMPULAN}

Berdasarkan hasil pengujian dan analisa pada pengerjaan penelitian ini dapat diambil kesimpulan bahwa hasil perancangan lambung katamaran dapat menampung beban maksimal dengan payload sebesar $4 \mathrm{Kg}$. Sensor konduktivitas mampu mendeteksi adanya minyak di air dengan konfigurasi rangkaian pembagian tegangan dengan ketebalan minimal 3mm. Navigasi pada Ardupilot mega mampu membuat kapal berjalan secara autonomous menuju titik waypoint. Sistem komunikasi antara kapal dengan 
ground control station menggunakan modul radio telemetry untuk transmisi data navigasi memiliki jarak pantau maksimal sebesar \pm 600 meter.

\section{DAFTAR PUSTAKA}

[1] L. Qu, J. Wang, S. Xin, M. Qin, and J. Dong, “A system for detecting sea oil leak based on video surveillance,” in 2011 Third Pacific-Asia Conference on Circuits, Communications and System (PACCS), 2011.

[2] R. Garello and V. Kerbaol, "Oil pollution monitoring: An integrated approach,” in 2017 IEEE Workshop on Environmental, Energy, and Structural Monitoring Systems (EESMS), 2017.

[3] M. Migliaccio, F. Nunziata, A. Montuori, X. Li, and W. G. Pichel, “A multifrequency polarimetric SAR processing chain to observe oil fields in the Gulf of Mexico,” IEEE Trans. Geosci. Remote Sens., vol. 49, no. 12, pp. 4729-4737, Dec. 2011.

[4] Z. S. Putra, M. Rivai, and S. Suwito, "Sistem sensor kualitas minyak berdasarkan pada pengukuran kapasitansi dan panjang berkas pembiasan cahaya,” J. Tek. ITS, vol. 2, no. 1, pp. B67-B72, Mar. 2013.
[5] Z. H. Arum, C. S. Widodo, and G. Saroja, "Studi pengukuran nilai konstanta dielektrik oli berbagai viskositas pada frekuensi $100 \mathrm{~Hz}$ 2000 Hz,” Brawijaya Phys. Student J., vol. 2, no. 1, 2014.

[6] N. B. Septyanto, M. Julius, and R. A. Setyawan, "Perancangan sensor konduktivitas dengan teknologi film tebal (Thick film),” Jur. Mhs. TEUB, vol. 2, no. 1, pp. 1-5, Dec. 2014.

[7] F. R. Saputra and M. Rivai, "Autonomous surface vehicle sebagai alat pemantau lingkungan menggunakan metode navigasi waypoint,” $J$. Tek. ITS, vol. 7, no. 1, pp. 76-81, Mar. 2018.

[8] A. Zurkoni, A. H. Alasiry, and I. K. Wibowo, "Rancang sistem multi navigasi dan pemantauan wilayah pada roboboat Autonomous Surface Vehicle (ASV),” Politeknik Elektronika Negeri Surabaya, 2016.

[9] D. A. R. Kurniawan, M. Rivai, and R. Dikairono, "Sistem navigasi pada balon udara menggunakan GPS dan kontrol logika fuzzy,” $J$. Tek. ITS, vol. 5, no. 2, pp. A173-A178, Aug. 2016.

[10] R. Watiasih, M. Rivai, R. A. Wibowo, and O. Penangsang, "Path planning mobile robot using waypoint for gas level mapping,” in 2017 International Seminar on Intelligent Technology and Its Applications (ISITIA), 2017, pp. 244-249.

[11] I. Priyanta, M. Rivai, and R. Dikairono, "Pemetaan distribusi gas polutan menggunakan quadcopter berbasis autonomous waypoint navigation,” vol. 5, no. 2, Jan. 2016. 